\title{
PENEGAKAN HUKUM TERHADAP APARAT SIPIL NEGARA YANG MELAKUKAN PELANGGARAN HUKUM DALAM MEWUJUDKAN GOOD GOVERNANCE
}

\author{
Oleh: \\ Muhammad Ansori Lubis ${ }^{1)}$, \\ Ria Sinta Dhevi ${ }^{2)}$ \\ Muhammad Yasid ${ }^{3)}$ \\ Universitas Darma Agung, Medan, 1,2,3) \\ E-mail: \\ muhammadansorilubis30@gmail.com $^{1)}$ \\ riasinthadevi04@gmail.com ${ }^{2)}$ \\ yasidfakultadhukum@gmail.com ${ }^{3)}$
}

\begin{abstract}
The purpose of this study is to find out, analyze and understand the procedures and mechanisms that are implemented in the implementation of good governance and good governance, to find out, analyze and understand the efforts undertaken in improving the understanding of all components of stakeholders about good governance and good governance, to know, analyze and understand the reality of law enforcement against civil servants committing criminal acts. Primary data were obtained from the field by conducting interviews and case studies with related parties. Secondary data obtained through library research or documentation studies to obtain secondary data. Through this research obtained thoughts, doctrines, opinions or conceptual thoughts from previous research relating to the object of research research In conducting research used legal materials consisting of primary law, secondary law, and tertiary law. The results of the study showed that the Procedure and implementation mechanism in the implementation of good governance and good governance. The orientation of good governance is: Ideal State orientation directed towards the achievement of national goals; This orientation, such as: legitimacy (whether the government is elected and won the trust of its people, accountability, securing of human rights, autonomy und devolution of power, and assurance of civilian control. Governance that functions ideally, namely effectively, efficiently in carrying out efforts to achieve rational objectives This orientation, depends on the extent to which the government has competence and the extent to which political and administrative structures and mechanisms function effectively and efficiently Efforts that must be made in improving the understanding of all stakeholders' components of good governance and good governance are that governance and good governance are at its base. not regulated in a law (Act) Achieving the socio-economic conditions above, the process of forming a democratic government is absolutely necessary State and Civil Society in which there is a private sector. Countries with government bureaucracy are required to to change the pattern of public service
\end{abstract}


from an elitist bureaucracy perspective to a populist bureaucracy. Populist bureaucracy is a governance system that is oriented towards serving and siding with the interests of society. Realizing the principles of Good and Clean Governance, regional autonomy policy can be used as a medium for the transformation of the realization of the model of governance that sustains the growth of democratic culture in Indonesia.

Keywords: law enforcement, violation of the law, good governance.

\begin{abstract}
ABSTRAK
Tujuan penelitian ini adalah untuk mengetahui, menganalisis dan memahami prosedur dan mekanisme yang implementatif dalam penyelenggaraan good governance dan pemerintahan yang baik, untuk mengetahui, menganalisis dan memahami usaha-usaha yang dilakukan dalam meningkatkan pemahaman seluruh komponen stakeholders tentang good governance dan pemerintahan yang baik, untuk mengetahui, menganalisis dan memahami realitas penegakan hukum terhadap PNS melakukan tindak Pidana. Data primer diperoleh dari lapangan dengan mengadakan wawancara dan studi kasus dengan pihak-pihak yang terkait. Data sekunder diperolch melalui penelitian kepustakaan atau studi dokumentasi untuk mendapatkan data sekunder. Melalui penelitian ini didapat pemikiranpemikiran, doktrin, pendapat atau pemikiran konseptual dari penelitian terdahulu yang berhubungan dengan objek telaahan penelitian Dalam melakukan penelitian digunakan bahan-bahan hukum yang terdiri dari hukum primer, hukum sekunder, dan hukum tertier.Hasil penelitian menunjukkan bahwa Prosedur dan mekanisme yang implementatif dalam penyelenggaraan good governance dan pemerintahan yang baik. Orientasi good governance adalah: Orientasi Ideal Negara yang diarahkan pada pencapaian tujuan nasional; Orientasi ini, seperti: legitimacy (apakah pemerintah dipilih dan mendapat kepercayaan dari rakyatnya, akuntabilitas, securing of human right, autonomy und devolution of power, dan assurance of civilian control. Pemerintahan yang berfungsisecara ideal, yaitu secara efektif, efisien dalam melakukan upaya mencapai tujuanrasional. Orientasi ini, tergantung pada sejauh mana pemerintahan mempunyai kompetensi dan sejauh mana struktur serta mekanisme politik dan administratifberfungsi secara efektif dan efisien. Usaha-usaha yang harus dilakukan dalam meningkatkan pemahaman seluruh komponen stakeholders tentang good governance dan pemerintahan yang baik adalah bahwa governance dan good governance pada dasarnya tidak diatur dalam sebuah undang-undang (UU) Mencapai kondisi sosial-ekonomi di atas, proses pembentukan pemerintahan yang berlangsung secara demokratis mutlak dilakukan. Negara dan Masyarakat Madani yang di dalamnya terdapat sektor swasta.Negara dengan birokrasi pemerintahannya dituntut untuk mengubah pola pelayananpublik dari perspektif birokrasi elitis menjadi birokrasi populis. Birokrasi populis adalah tata kelola pemerintahan yang berorientasi melayani dan berpihak kepada kepentingan masyarakat. Merealisasikan prinsip-prinsip Good and Clean Governance, kebijakan otonomi
\end{abstract}


daerah dapat dijadikan sebagai media transformasi perwujudan model pemerintahan yang menopang tumbuhnya kultur demokrasi di Indonesia.

Kata Kunci: penegakan hukum, pelanggaran hukum, good governance.

\section{PENDAHULUAN}

Undang-Undang Dasar 1945 menurut para penyusunnya mengandung perintah yang mewajibkan pemerintah/ penyelenggara negara untuk memelihara budi pekerti kemanusiaan yang luhur dan memegang teguh cita-cita moral rakyat yang luhur. Ketenteraman tersebut sebagai konsekuensi dari pokok-pokok pikiran yang termuat dalam Pembukaan Undang-Undang Dasar itu, yaitu Negara berdasarkan atas asas Ketuhanan Yang Maha Esa menurut dasar Kemanusiaan yang Adil dan Beradab. Pembangunan nasional sebagaimana tersebut dalam Undang-undang Dasar Negara Republik Indonesia Tahun 1945, bertujuan untuk membentuk manusia Indonesia seutuhnya baik secara materil, maupun spiritual berdasarkan Pancasila dan UndangUndang Dasar 1945dalam kehidupan berbangsa danber negara. Salah satu tujuan pembangunan nasional adalah untuk dapat mewujudkan tujuan kemasyarakatan yaitu kesejahteraan dan keadilan dalam masyarakat. Pembangunan secara materil dalam hubungannya dengan sumber daya manusia, berarti pembangunan unsur-unsur diluar kejiwaan manusia seperti pembangunan ekonomi, teknologi, dan sarana-sarana fisik kehidupan, sedangkan pembangunan spiritual berarti pembangunan unsure - unsur kejiwaaan manusia seperti pembangunan moral dan pembangunan pendidikan.

Sejak diberlakukannya Undang-Undang Dasar 1945 sampai terjadinya gerakan reformasi telah ada beberapa ketetapan Majelis Permusyawaratan Rakyat dan peraturan perundang-undangan lain yang dapat dianggap sebagai aturan pelaksanaan dari ketentuan konstitusional itu, seperti perundangundangan Pidana Umum undangundang korupsi, TAP MPR tentang Pedoman Penghayatan dan Pengamalan Pancasila, Undangundang Pokok Kepegawaian, Peraturan Pemerintah tentang Disiplin Pegawai Negeri dan lainlain, tetapi pelaksanaannya tidak mencapai sasaran secara optimal, malah korupsi dan penyalahgunaan wewenang terus meluas sehingga akhirnya timbul gerakan rakyat berupa reformasi total yang sampai saat belum tuntas.

MPR hasil awal reformasi telah menetapkan Kebijakan Nasional tentang upaya mewujudkan penyelenggaraan negara yang bersih dari Korupsi dan Nepotisme (KKN).

a. Dalam konsiderans Tap MPR No. XI/MPR/1998 ditentukan bahwa MPR mengkonstatir terjadinya penyelenggaraan negara dengan pemutusan kekuasaan, wewenang dan tanggung jawab pada Presiden Mandataris MPR yang berakibat tidak berfungsinya lembagalembaga tinggi negara serta tidak 
berkembangnya partisipasi masyarakat dalam memberikan kontrol sosial dalam kehidupan bermasyarakat, berbangsa dan bernegara. MPR juga berpendapat bahwa tuntutan hati nurani rakyat menghendaki adanya penyelenggara negara yang mampu menjalankan fungsi dan tugasnya secara bersungguh-sungguh dan penuh tanggung jawab agar reformasi pembangunan dapat berdayaguna dan berhasil guna.

b. Di samping itu MPR menyatakan keyakinannya bahwa dalam penyelenggaraan negara telah terjadi praktek usaha yang lebih menguntungkan sekelompok tertentu yang menyuburkan korupsi, kolusi dan nepotisme yang melibatkan para pejabat negara dengan para pengusaha sehingga merusak sendi-sendi penyelenggaraan negara dalam berbagai aspek kehidupan nasional."Dalam rangka merehabilitasi seluruh kehidupan nasional yang berkeadilan, dibutuhkan penyelenggaraan negara yang dapat dipercaya, melalui usaha pemeriksaan harta kekayaan para pejabat negara dan mantan pejabat negara serta keluarganya yang diduga berasal dari praktek korupsi, kolusi dan nepotisme" demikian ketetapan Lembaga Negara Tertinggi.

Sidang tahunan Majelis Permusyawaratan Rakyat yang diselenggarakan tanggal 10 sampai dengan 13 Nopember 1998 telah membahas masalah korupsi, kolusi dan nepotisme yang bahan-bahannya disiapkan oleh Badan Pekerja Majelis Permusyawaratan Rakyat dan pada hari itu juga ditetapkan Ketetapan Majelis Permusyawaratan Rakyat Nomor XI/MPR/1998. Berdasarkan TAP MPR tersebut penyelenggaraan negara pada lembaga-lembaga eksekutif, legislatif dan yudikatif, harus melaksanakan fungsi dan tugasnya dengan baik dan bertanggungjawab kepada masyarakat, bangsa dan negara.

Menjalankan fungsi dan tugasnya tersebut, penyelenggara harus jujur, adil, terbuka dan terpercaya serta mampu membebaskan dari praktik korupsi, kolusi dan nepotisme. Menghindarkan praktik-praktik Korupsi, Kolusi dan Nepotisme; seseorang yang terpercaya menjabat suatu jabatan dalam penyelenggaraan negara harus bersumpah sesuai dengan agamanya, harus mengumumkan dan bersedia diperiksa kekayaannya sebelum dan setelah menjabat. Pemeriksaan atas kekayaan sebagaimana dimaksud tadi, dilakukan oleh Kepala Negara yang keanggotaannya terdiri dari Pemerintah dan Masyarakat.Upaya pemberantasan tindak pidana korupsi dilakukan secara tegas dengan melaksanakan secara konsisten penegakan hukum.

Supaya pemberantasan KKN
harus dilakukan secara tegas terhadap siapapun juga, baik pejabat negara, mantan pejabat negara, kelompok dan kroninya maupun pihak swasta/ konglomerat dengan tetap memperhatikan prinsip praduga tak bersalah dan hak-hak asasi manusia.

Penyelenggara negara mempunyai peran penting dalam 
mewujudkan cita-cita perjuangan bangsa. Hal ini secara tegas dinyatakan dalam penjelasan Undang-Undang Dasar 1945 yang menentukan bahwa yang sangat penting dalam pemerintahan dan dalam hal hidupnya negara ialah semangat para Penyelenggara Negara dan pemimpin pemerintahan.

Dalam kenyataannya, Penyelenggara Negara tidak dapat menjalankan tugas dan fungsinya secara optimal, sehingga penyelenggara Negara tidak berjalan sebagaimana mestinya, hal itu terjadi karena adanya pemusatan kekuasaan, wewenang dan tanggungjawab pada Presiden/Mandataris Majelis Permusyawaratan Rakyat Republik Indonesia. Masyarakat pun belum sepenuhnya berperan serta dalam menjalankan fungsi kontrol sosial yang efektif terhadap penyelenggaraan negara.

Pemusatan kekuasaan, wewenang dan tanggungjawab tersebut tidak hanya berdampak negatif di bidang politik, namun juga di bidang ekonomi dan moneter, antara lain terjadinya penyimpanganpenyimpangan.

Penyelenggaraan Negara, antar Penyelenggaraan Negara yang lebih menguntungkan kelompok tertentu dan memberi peluang terhadap tumbuhnya korupsi, kolusi, dan nepotisme.Tindak pidana korupsi, kolusi, dan nepotisme tersebut tidak hanya dilakukan oleh Penyelenggara negara antar Penyelenggara negara melainkan juga Penyelenggara negara dengan pihak lain seperti keluarga, kroni dan para pengusaha, sehingga merusak sendi-sendi kehidupan bermasyarakat, berbangsa dan bernegara, serta membahayakan eksistensi negara.

Kesamaan visi, persepsi, dari korupsi, kolusi dan nepotisme, sebagaimana diamanatkan oleh Ketetapan MPR Nomor XI/MPR/1998 tentang Penyelenggara Negara yang bersih dan bebas korupsi, kolusi dan nepotisme (KKN).Undang-undang tersebut diatas memuat ketentuan yang berkaitan langsung atau tidak langsung dengan penegakan hukum terhadap tindak pidana korupsi, kolusi, dan nepotisme yang khusus ditujukan kepada para Penyelenggara Negara dan pejabat lain yang memiliki fungsi strategis dalam kaitannya dengan Penyelenggara Negara sesuai dengan ketentuan peraturan perundang-undangan yang berlaku.

\section{TINJAUAN PUSTAKA}

Undang-undang Nomor 28 Tahun 1999 itu merupakan bagian atau sub-sistem dari peraturan perundang-undangan yang berkaitan dengan penegakan hukum terhadap perbuatan korupsi, kolusi, dan nepotisme. Sasaran pokok undangundang ini meliputi para Penyelenggara Negara, Pejabat Negara pada Lembaga Tertinggi Negara dan atau pejabat lain yang memiliki fungsi strategis dalam kaitannya dengan penyelenggaraan negara sesuai dengan ketentuan peraturan perundang-undangan yang berlaku.

Mewujudkan

penyelenggaraan negara yang bersih dan bebas dari korupsi, kolusi dan nepotisme, dalam undang-undang ini ditetapkan asas-asas umum penyelenggaraan negara yang 
meliputi asas kepastian hukum, asas tertib penyelenggaraan negara, asas kepentingan umum, asas keterbukaan, asas proporsionalitas, asas profesionalitas, dan asas akuntabilitas.Pengaturan tentang peran serta masyarakat dalam undang-undang ini dimaksud untuk memberdayakan masyarakat dalam rangka mewujudkan penyelenggara negara yang bersih dan bebas dari korupsi, kolusi, dan nepotisme.

Berdasarkan hak dan kewajiban yang dimiliki, masyarakat diharapkan dapat lebih bergairah melaksanakan kontrol sosial secara optimal terhadap penyelenggaraan negara dengan tetap menaati ramburambu hukum yang berlaku. Agar undang-undang dimaksud dapat mencapai sasaran secara efektif maka diatur pembentukan Komisi Pemeriksa yang bertugas dan berwenang melakukan pemeriksaan harta kekayaan pejabat negara, sebelum, selama dan setelah menjabat termasuk meminta keterangan, baik dari mantan pejabat negara, keluarga dan kroninya maupun para pengusaha, dengan tetap memperhatikan prinsip praduga tak bersalah dan hak asasi manusia.

$$
\text { Susunan keanggotaan }
$$

Komisi Pemeriksa terdiri atas unsur Pemerintah dam masyarakat mencerminkan independensi atau kemandirian dari lembaga ini. Dalam Undang-undang diatur tentang kewajiban para Penyelenggara Negara antara lain mengumumkan dan melaporkan harta kekayaannya sebelum dan setelah menjabat. Ketentuan tentang sanksi dalam undang-undang ini berlaku bagi Penyelenggara Negara, Masyarakat dan Komisi Pemeriksa sebagian upaya prepentif dan refresif serta berfungsi sebagai jaminan atas ditaatinya ketentuan tentang asas umum penyelenggara negara, hak dan kewajiban penyelenggara negara, sehingga dapat diharapkan memperkuat norma kelembagaan moralitas dan sosial.

Mengabaikan azas-azas moral dan budi pekerti kemanusiaan yang luhur seperti diperintahkan oleh Undang-Undang Dasar1945, akan berarti tidak "bersih" dilihat dari segi moral dan atau etika. Keharusan untuk mewujudkan Pemerintah yang "bersih" merupakan kaidah yang normatif konstitusional. Sifat bersih akan mempunyai daya tarik yang simpatik, mengundang sikap berpartisipasi. Sebaliknya sifat kotor, menimbulkan sifat negatif, karena akan menjauhkan sikap simpati, malah mengundang sikap masa bodoh dari pihak-pihak yang seharusnya berpartisipasi.

Hubungannya sifat bersih dengan timbulnya daya tarik untuk berpartisipasi dengan sifat "kuat dan berwibawa" nya suatu perintah. Pemerintah tidak diletakkan ditangan seorang. Pemerintah di jalankan oleh Presiden dengan dibantu oleh sekian banyak pembantunya. Para pembantunya juga tidak dapat berbuat tanpa bantuan rakyat. Rakyat baru mau membantu kalau yang perlu dibantu berlaku dan dapat menarik simpati. Pemerintah yang kuat adalah Pemerintah yang mendapat simpati dari rakyatnya, mendapat dukungan karena tidak Koruppsi, Kolusi dan Nepotisme dan tidak sewenang-wenang.

Dukungan rakyat terhadap pemerintahnya yang dapat menarik simpati mereka dapat timbul karena 
tindakan dan kebijakannya diyakini kebenarannya oleh rakyat, mencerminkan aspirasi rakyat yang telah terbukti dan terasa sesuai dengan apa yang didambakannya. Pemerintah yang demikian bukan hanya berkuasa secara formal, mempunyai kekuatan dengan kekuasaannya itu, melainkan meningkat menjadi pemerintah yang berwibawa. Artinya kekuatan dan kekuasaannya diterima serta didukung oleh rakyatnya, tetapi masalahnya tidak sesederhana. Kedisipinan dlam bekerja akan meningkatkan kemandirian serta mengurangi resiko tidak masuk kerja atau korupsi waktu dalam bekerja Siregar P (2019), Panggabean N (2018).

Kelancaran pelaksanaan pembangunan dan pemerintahan tergantung pada kesempurnaan dan kemampuan aparatur negara, dalam hal ini adalah Pegawai Negeri. Kedudukan dan peranan Pegawai Negeri dalam setiap organisasi pemerintahan sangatlah menentukan, sebab Pegawai Negeri merupakan tulang punggung pemerintah dalam melaksanakan pembangunan nasional.

Peranan dari Pegawai Negeri seperti diistilahkan dalam dunia kemiliteran

berbunyi "Notthegun, the

manbehindthegun"yaitu bukan senjata yang penting melainkan manusia yang menggunakan senjata itu.

Senjata yang modern tidak mempunyai arti apa-apa apabila manusia yang dipercaya menggunakan senjata itu tidak melaksanakan kewajibannya dengan benar. Pegawai Negeri Sipil sebagai abdi Negara dan abdi masyarakat yang dengan penuh kesetian dan ketaatan kepada Pancasila, UndangUndang Dasar1945, Negara dan Pemerintah dalam menyelenggarakan tugas pemerintahan dan pembangunan serta wajib menjaga persatuan dan kesatuan bangsa dalam Negara Kesatuan Republik Indonesia.

Tugas kenegaraan dan jabatan yang diemban Pegawai Negeri agar dapat berjalan dengan lancar,dan dapat menunjang kelancaran pembangunan Nasional, maka setiap Pegawai Negeri tersebut harus memiliki kemampuan dan kualitas tinggi serta dengan tingkat disiplin yang tinggi pula. Hal tersebut tidak hanya kemampuan dalam bidang keterampilannya saja, akan tetapi harus didukung dengan tingkat kualitas diri secara total, karena kualitas manusia itu ditentukan oleh KSA (Knowledge, Skill, and Attitude) atau pengetahuan, keterampilan, dan sikap mental.

Intinya jelas terlihat bahwa suatu keterampilan yang dimiliki seseorang tidak cukup untuk bias dikatakan bahwa orang tersebut mempunyai kualitas diri yang baik.

Penyelenggara pemerintahan yang telah mempunyai kualitas tersebut,maka dapat memberikan pelayanan kepada masyarakat secara profesional, jujur, adil, dan merata dalam penyelenggaraan tugas negara, pemerintahan dan pembangunan dapat berjalan secara efektif.

Kualitas Pegawai Negeri yang baik dalam setiap aparatur Negara, akan menumbuhkan rasa tanggung jawab baik secara materill maupun moril terhadap semua tugastugasyang dipikulnya, serta tumbuh 
kesadaran untuk selalu menjunjung tinggi peraturan yang ada.

Pemerintah dalam rangka melaksanakan ketentuan Pasal 30 Undang-Undang Nomor 43 Tahun 1999, mengganti Peraturan Pemerintah Nomor 30 Tahun 1980 yang Surat Edaran Kepala Badan Administrasi Kepegawaian Negara Nomor 21 Tahun 2010, yang sesuai dengan kebutuhan dan perkembangan keadaan, maka diberlakukanlah Peraturan Pemerintah Nomor 53 Tahun 2010 tentang Disiplin Pegawai Negeri Sipil.

Ketentuan pelaksanaan

Peraturan Pemerintah Nomor 53 tersebut, ditetapkan dalam Surat menetapkan kewajiban dan larangan bagi Pegawai Negeri Sipil tersebut. Adapun kewajiban tersebut termuat dalam Pasal 3 yangberbunyi sebagai berikut:

1. Mengucapkan sumpah/janji PNS;

2. Mengucapkan sumpah/janjijabatan;

3. Setia dan taat sepenuhnya kepada Pancasila, UndangUndang Dasar Negara RepublikIndonesia Tahun 1945, Negara Kesatuan Republik Indonesia,dan Pemerintah;

4. Menaati segala ketentuan peraturan perundang-undangan;

5. Melaksanakan tugas kedinasan yang dipercayakan kepada PNS dengan penuh pengabdian, kesadaran, dan tanggungjawab;

6. Menjunjung tinggi kehormatan negara, Pemerintah, dan martabat PNS;

7. Mengutamakan kepentingan negara dari pada kepentingan sendiri, seseorang, dan/ ataugolongan;

8. Memegang rahasia jabatan yang menurut sifatnyaa tau menurut perintah harus dirahasiakan;

9. Bekerja dengan jujur, tertib, cermat, dan bersemangat untuk kepentingan negara;

10. Melaporkan dengan segera kepadaa tasannya apabila mengetahui ada hal yang dapat membahayakan atau merugikan negara atau Pemerintah terutama dibidang keamanan, keuangan, dan materiil;

11. Masuk kerjadan menaati ketentuan jam kerja;

12. Mencapai sasaran kerja pegawai yang ditetapkan;

13. Menggunakan dan memelihara barang-barang milik Negara dengan sebaik- baiknya;

14. Memberikan pelayanan sebaikbaiknya kepada masyarakat;

15. Membimbing bawahan dalam melaksanakan tugas;

16. Memberikan kesempatan kepada bawahan untuk mengembangkan karier; Dan,

17. Menaati peraturan kedinasan yang ditetapkan oleh pejabat yang berwenang.

Mengenai larangan Pegawai Negeri Sipil termuat dalam Pasal 4 yang menentukan sebagai berikut:

1. Menyalahgunakan wewenang;

2. Menjadi perantara untuk mendapatkan keuntungan pribadi dan/atau orang lain dengan menggunakan kewenangan orang lain;

3. Tanpa izin Pemerintah menjadi pegawai atau bekerja untuk Negara lain dan/atau lembaga atau organisasi internasional; 
4. Bekerja pada perusahaan asing, konsultan asing, atau lembaga swadaya masyarakat asing;

5. Memiliki,menjual,membeli,meng gadaikan,menyewakan, meminjamkan barang-barang baik bergerak atau tidak bergerak, dokumen atau surat berharga milik Negara secara tidak sah;

6. Melakukan kegiatan bersama dengan atasan, teman sejawat,bawahan,atauorang lain di dalam maupun di luar lingkungan kerjanya dengan tujuan untuk keuntungan pribadi,golongan,atau pihaklain,yang secara langsung atau tidak langsung merugikan negara;

7. Memberi atau menyanggupiakan memberi sesuatu kepada siapapun baik secara langsung atautidak langsung dan dengan dalih apapun untuk diangkat dalam jabatan;

8. Menerima hadiah atau suatu pemberian apa saja dari siapapun juga yang berhubungan dengan jabatan dan/atau pekerjaannya;

9. Bertindak sewenang-wenang terhadap bawahannya;

10. Melakukan suatu tindakan atau tidak melakukan suatu tindakan yang dapat menghalangi atau mempersulit salah satu pihak yang dilayani sehingga mengakibatkan kerugian bagi yang dilayani;

11. Menghalangi berjalannya tugas kedinasan;

12. Memberikan dukungan kepada calon Presiden/Wakil Presiden, Dewan Perwakilan Rakyat, Dewan Perwakilan Daerah, atau Dewan Perwakilan Rakyat Daerah.
Kewajiban dan larangan teresebut, apabila dilanggar atau tidakdipatuhi akan dikenakan sanksi hukuman disiplin sesuai dengan tingkat kesalahannya. Pegawai Negeri Sipil selain ketentuan diatas tentang adanya larangan dan kewajiban, juga mempunyai hak-hak untuk digunakan sepertiyang tertera didalam Undang-Undang Nomor 43 Tahun1999. Peraturan mengenai kedisiplinan Pegawai Negeri Sipil telah dibentuk dan diberlakukan,tidak jarang ditemukan adanya pelanggaran-pelanggaran terhadap kedisiplinan tersebut. Pelanggaran disiplin Pegawai Negeri Sipil,bisasaja dikarenakan oleh hakhak yang diperolehnya tidak sesuai dengan kebutuhan hidupnya, sebagaimana kita ketahui bahwa kebutuhan manusia pada masa sekarang ini semakin kompleks, akan tetapi mungkin kebutuhan hidup yang semakin banyak tersebut bukan merupakan satu-satunya faktor penyebab terjadinya pelanggaran. Pemerintah telah menaikan gaji serta tunjangan, namun tetap saja terjadi pelanggaran, kemungkinan factor utama yang menjadi hambatan kedisiplinan Pegawai Negeri Sipili tuterletak pada diri pegawai itu sendiri. Tindakan yang menyimpang seperti: korupsi, penyalahgunaan wewenang,dan pemborosan keuangan negara, pungutan liar, dan berbagai bentuk pelanggaran tersebut akan selalu terjadi, bila dalam diri PNS belum terbentuk suatu kesadaran dan suatu etika yang dituangkan dalam Nilai-nilai Perilaku Kedinasan.

METODE PENELITIAN 
Penelitian yang digunakan adalah penelitian Hukum Empiris (Yuridis Sosiologis) yaitu penelitian tentang prosedur dan mekanisme yang implementatif dalam penyelenggaraan good governancedan pemerintahan yang baik, usaha-usaha yang dilakukan dalam meningkatkan pemahaman seluruh komponen stake holders tentang good governance dan pemerintahan yang baik, realitas penegakan hukum terhadap Pegawai Negeri Sipilyang melakukan tindak Pidana.

Data yang dipergunakan dalam penelitian iniadalah data primer dan data sekunder. Data primer diperoleh dari lapangan dengan mengadakan wawancara dan studi kasus dengan pihak-pihak yang terkait.

Data sekunder diperoleh melalui penelitian kepustakaan atau studi dokumentasi untuk mendapatkan data sekunder. Melalui penelitian ini didapat pemikiran-pemikiran, doktrin, pendapat atau pemikiran konseptual dari penelitian terdahulu yang berhubungan dengan objek telaahan penelitian ini.

Dalam melakukan penelitian digunakan bahan-bahan hukum yang terdiri dari:

a. Bahan hukum primer, yaitu bahan-bahan hukum yang mengikat, terdiri dari peraturan perundang-undangan yang berkaitan dengan pokok permasalahan.

b. Bahan hukum sekunder, yaitu bahan yang memberikan penjelasan mengenai bahan hukum primer, berupa hasil penelitian para ahli, hasil-hasil karya ilmiah, buku-buku ilmiah, dan sebagainya. c. Bahan hukum tertier, yaitu bahan-bahan yang memberi petunjuk penjelasan terhadap bahan hukum primer dan sekunder, antara lain kamus hukum, kamus bahasa Indonesia, ensiklopedi dan lain sebagainya.

Penelitian ini dilakukan diBadan Kepegawaian Daerah Kabupaten Nias Selatan.Sesuai dengan sifat penelitian maka analisis data dilakukan secara kualitatif, yaitu dengan cara mempelajari, memahami semua data yang ada. Selanjutnya dianalisis dengan menafsirkan dengan metode induktif dan deduktif, sehingga dapat ditarik kesimpulan dalam rangka menjawab permasalah yang diteliti.

\section{HASIL DAN PEMBAHASAN \\ Prosedur Dan Mekanisme Yang Implementatif Dalam Penyelenggaraan Good Governance Dan Pemerintahan Yang Baik}

Penyelenggara negara meliputi: Pejabat Negara pada Lembaga Tertinggi Negara, Pejabat Negara pada Lembaga Tinggi Negara, Menteri, Gubemur, Hakim, Pejabat negara yang lain yang sesuai dengan ketentuan peraturan perundang-undangan yang berlaku, dan Pejabat lain yang memiliki fungsi strategis dalam kaitannya. Dengan Penyelenggara Negara sesuai dengan ketentuan perundangundangan yang berlaku.

Hak dan Kewajiban Penyelenggara Negara, setiap Penyelenggara Negara berhak untuk:

a. Menerima gaji, tunjangan dan fasilitas lainnya sesuai dengan peraturan dengan ketentuan peraturan perundang-undangan 
yang berlaku;

b. Menggunakan hak jawab terhadap setiap teguran, tindakan dari atasannya, ancaman hukuman, dan kritik masyarakat.

c. Menyampaikan pendapat di muka umum secara bertanggung jawab sesuai dengan wewenangnya;

d. Mendapatkan hak-hak lain sesuai dengan ketentuan peraturan perundangundangan yang berlaku.

Setiap Penyelenggara Negara berkewajiban untuk:

a. Mengucapkan sumpah atau janji sesuai dengan agamanya sebelum memangku jabatannya;

b. Bersedia diperiksa kekayaannya sebelum, selama, dan setelah menjabat;

c. Melaporkan dan mengumumkan kekayaannya sebelum dan setelah menjabat;

d. Tidak melakukan perbuatan korupsi, kolusi dan nepotisme;

e. Melaksanakan tugas tanpa membeda-bedakan suku, agama, ras, dan golongan;

f. Melaksanakan tugas dengan penuh rasa tanggung jawab dan tidak melakukan perbuatan tercela, tanpa pamrih baik untuk kepentingan pribadi, keluarga, kroni, maupun kelompok, dan tidak mengharapkan imbalan dalam bentuk apapun yang bertentangan dengan ketentuan peraturan perundang-undangan yang berlaku;

g. Bersedia menjadi saksi dalam perkara korupsi, kolusi, dan nepotisme serta dalam perkara lainya sesuai dengan ketentuan peraturan perundang-undangan yang berlaku;
Hak dan kewajiban penyelenggara Negara sebagaimana dimaksud dalam Pasal 4 dan Pasal 5 dilaksanakan sesuai dengan ketentuan Undang-Undang Dasar 1945 dan peraturan perundangundangan yang berlaku. Terselenggaranya pemerintahan yang baik, bersih dan berwibawa (clean and good governance) menjadi citacita dan harapan setiap bangsa. Governance adalah mekanisme pengelolaan sumber daya ekonomi dan social yang melibatkan pengaruh sektor Negara dan sektor non pemerintah dalam suatu kegiatan kolektif. Good dalam good gavernance, mengandung 2 (dua) pengertian:

a. Nilai-nilai yang menjunjung tinggi keinginan/kehendak rakyat, dan nilai-nilai yang dapat meningkatkan kemampuan rakyat yang dalam pencapaian tujuan (nasional) kemandirian, pembangunan berkelanjutan dan keadilan sosial;

b. Aspek-aspek fungsional dari pemerintah yang efektif dan efisien dalam melakukan upaya mencapai tujuan nasional.

Orientasi good gavernance adalah:

a. orientasi ideal Negara yang diarahkan pada pencapaian tujuan nasional; Orientasi ini, seperti: legitimacy (apakah pemerintah dipilih dan mendapat kepercayaan dari rakyatnya), accountability (akuntabilitas), scuring of human right, autonomy and devolution of power, dan assurance of civilian control;

b. pemerintahan yang berfungsi secara ideal, yaitu secara efektif, 
efisien dalam melakukan upaya mencapai tujuan nasional. Orientasi ini, tergantung pada sejauh mana pemerintahan mempunyai kompetensi, dan sejauh mana struktur serta mekanisme politik dan administratif berfungsi secara efektif dan efisien.

Berdasarkan uraian ini dapat dikatakan bahwa wujud good governance adalah penyelenggaraan pemerintahan negara yang solid dan bertanggungjawab, serta efisien, efektif, dengan menjaga 'kesinergisan" interaksi yang konstruktif di antara domain-domain negara, sektor swasta dan masyarakat (society).

United Nations Development Programme (UNDP) mengajukan beberapa karakteristik good gavernance, yaitu:

a. Participation; Setiap warga negara mempunyai suara dalam pembuatan keputusan, baik secara langsung, maupun melalui intermediasi institusi legitimasi yang mewakili kepentingannya. Partisipasi seperti ini dibangun atas dasar kebebasan berasosiasi dan berbicara serta berpartisipasi secara konstruktif;

b. Rule of law; Kerangka hukum harus adil dan dilaksanakan tanpa pandang bulu, terutama hukum untuk hak asasi manusia;

c. Transparancy; Transparansi dibangun atas dasar kebebasan arus informasi. Proses-proses, lembaga-lembaga dan informasi secara langsung dapat diterima oleh mereka yang membutuhkan. Informasi harus dapat difahami dan dapat dimonitor;

d. Responsiveness. Lembagalembaga dan proses-proses harus mencoba untuk melayani setiap 'stakeholders'.

e. Concensus orientation; Good governance menjadi perantara kepentingan yang berbeda untuk memperoleh pilihan-pilihan terbaik bagi kepentingan yang lebih luas, baik dalam hal kebijakan-kebijakan maupun prosedur-prosedur;

f. Equity; Semua warga Negara, baik laki-laki maupun perempuan, mempunyai kesempatan untuk meningkatkan atau menjaga kesejahteraan mereka;

g. Efectiveness and efficiency; Proses-proses dan lembagalembaga sebaik mungkin menghasilkan sesuai dengan apa yang digariskan dengan menggunakan sumber-sumber yang tersedia;

h. Accountability; Para pembuat keputusan dalam pemerintahan, sector swasta dan masyarakat (civil society) bertanggungjawab kepada publik dan lembagalembaga 'stakeholders'. Akuntabilitas ini tergantung pada organisasi dan sifat keputusan yang dibuat, apakah keputusan tersebut untuk kepentingan internal atau eksternal organisasi;

i. Strategic vision; Para pemimpin dan publik harus mempunyai perspektif good governance dan pengembangan manusia yang luas dan jauh ke depan sejalan dengan apa yang diperlukan 
untuk pembangunan semacam ini.

Dalam pendahuluan telah disinggung tentang kewibawaan sebagai syarat untuk berhasil baiknya pelaksanaan tugas pemerintah negara hukum dan negara kesejahteraandalam mencapai tujuan nasional. Untuk itu diperlukan adanya Pegawai Negeri Sipil sebagai unsur Aparatur negara, abdi Negara dan Abdi Masyarakat yang setia taat kepada Pancasila Undang-Undang Dasar1945, Negara dan Pemerintah serta bersatu padu, bermental baik, berdayaguna, bersih, bermutu tinggi, sadar akan tanggungjawabnya dalam menjalankan tugas pemerintahan dan pembangunan dan akhirnya yang berwibawa.

Membina Pegawai Negeri Sipil termaksud Pemerintah berdayaupaya terus menerus dengan jalan antara lain :

a. Memberlakukan sanksi-sanksi hukum pidana seperti ketentuan Kitab Undang-undang Hukum Pidana (Pasal 413 s/d Pasal 437, Pasal 552 s/d Pasal 559), dan Undang Undang Anti Korupsi.

b. Mengadakan penataran Pedoman Penghayatan dan Pengamalan Pancasila, UUD'45, Garis-garis Besar Haluan Negara, Doktrin serta Kode Etika Korps Pegawai Republik Indonesia sebagai suatu gerakan didasarkan kepada Intruksi Presiden Nomor 10 Tahun 1978.

c. Menetapkan berbagai peraturan lain

\footnotetext{
Usaha-Usaha

Dalam

Meningkatkan Pemahaman Stake Holders Tentang Good Governance Dan Pemerintahan Yang Baik
}

Kedudukan Pegawai Negeri Sipil didasarkan pada Undang-Undang Nomor 43Tahun1999 Pasa 13 ayat(1), yaitu Pegawai Negeri sebagai unsur aparatur negara yang bertugas untuk memberikan pelayanan kepada masyarakat secara profesional, jujur, adil, dan merata dalam penyelenggaraan tugas negara, pemerintahan, dan pembangunan. Rumusan kedudukan Pegawai Negeri didasarkan pada pokok-pokok pikiran bahwa pemerintah tidak hanya menjalankan fungsi umum pemerintahan. Pemerintah juga harus mampu melaksanakan fungsi pembangunan atau dengan kata lain, pemerintah bukanhanya menyelenggarakan tertib pemerintahan, tetapi juga harus mampumenggerakkan dan memperlancar pembangunan untuk kepentingan rakyat banyak. Pegawai Negeri mempunyai perananamat penting sebab Pegawai Negeri merupakan unsure aparatur negara untuk menyelenggarakan pemerintahandan pembangunan dalam rangka mencapai tujuan negara. Kelancaran pelaksanaan pemerintahan dan pembangunan nasional tergantung pada kesempurnaana paratur negara. Pegawai Negeri Sipil dalam konteks hukum publik, bertugas membantu Presiden sebagai Kepala Pemerintahan dalam menyelenggarakan pemerintahan, tugas melaksanakan peraturan perundang-undangan, dalam artian wajib mengusahakan agar setiap peraturan perundang-undangan ditaati oleh masyarakat. Seorang Pegawai Negeri sebagai abdi negara juga wajib setia dan taat kepada 
Pancasila sebagai falsafah dan ideology negara, kepada UndangUndang Dasar1945, kepada negara, dan kepada pemerintah. Pegawai Negeri Sipil mempunyai kesetiaan, ketaatan penuh terhadap Pancasila,Undang-Undang Dasar 1945, Negara dan Pemerintah,pada akhirnya dapat memusatkan segala perhatian dan pikiran serta mengerahkan segala daya upaya dan tenaganya untuk menyelenggarakan tugas pemerintahan dan pembangunan secara berdaya guna dan berhasi lguna. Halter sebut juga berlaku bagi Pegawai Negeri Sipil, dalam melaksanakan tugas pokok dan fungsinya sebagaiunsuraparatur negara, abdi Negara dan abdi masyarakat yang dituntutuntuk dapat melaksanakan tugas dengan sebaikbaiknya,serta memiliki ketaatan dan kesetiaan terhadap Pancasila, Undang-Undang Dasar 1945, Negara dan Pemerintah.

\section{Realitas Penegakan Hukum Terhadap Pns Yang Melakukan Tindak Pidana}

Penyebab tidak terjadi Clean

Government, yaitu ada 4 aspek:

1. Aspek individu; merupakan penyakit sosial yang berkaitan dengan moral dan akhlak manusia

2. Aspek organisasi; berkaitan dengan sistem akuntabilitas kinerja dan kelemahan dalam sistem pengendalian mana jemen unit serta kultur organisasi yang kurang mendukung

3. Aspek masyarakat; berkaitan dengan nilai-nilai yang berlaku dimasyarakat yang kurang mendukungnya clean

\section{government}

4. Aspek peraturan perundangundangan; terkait dengan kualitas peraturan perundangundangan yang belum memadai

Mengatasi

ketidak

terlaksananya Good and Clean Government, pemerintahan di daerah membuat strategi untuk melaksanakan Good and Clean Government. Strategi tersebut dibagi menjadi 3 tahap strategi, yaitu:

a) Strategi Preventif: mencegah timbulnya penyelewengan, penyalahgunaan wewenang, inefisiensi, tidak efektif, tidak hemat dan KKN. Pembuatan LAKIP

b) Strategi Detektif: upaya untuk dapat mengetahui secara dini dalam waktu sesingkatsingkatnya dan seakuratakuratnya agar penyimpangan dapat ditindak lanjuti dengan cepat serta tepat untuk mencegah kerugian Negara atas penyimpangan.

c) Strategi Represif: upaya untuk menyelesaikan secara hukum dengan sebaik-baiknya atas penyimpangan yang telah terjadi.

Sudah dijelaskan di atas tentang gambaran apa itu Good and Clean Government secara umum. Apabila kita lihat kepada keadaan Negara kita sekarang ini, Indonesia, maka masih belumlah berjalan dengan baik. Indonesia saat ini sedang berada dalam keadaan krisismultidimensi. Keterbatasan akses atas sumberdaya dan kemampuan manajerial pemerintah adalah pemicu awal terjadinya krisismultidimensi ini. Padahal persaingan global dan pergerakan 
negara-negara Barat ke Indonesia menjadi atmosfir yang tidak baik bagi Indonesia, atau bahkan bisa menjatuhkan Indonesia itu sendiri. Beberapa sumberdaya berada di bawah kuasa sekelompok kecil orang atau dalam kata lain beberapa sumberdaya di Indonesia telah dimonopoli oleh sebagian orang yang berkuasa. Sementara itu masyarakat sebagian besar hanya menjadi obyek atau terkecilkan dari setiap bentuk partisipasi dalam proses pengambilan keputusan publik.

Multi krisis tadi bahkan lebih dari itu, krisis kepemimpinan dimana hanya melihat kepentingan sedikit orang daripada kebaikan untuk seluruhnya (public), pendayagunaan sumberdaya yang dimiliki masih kurang dan malah melibatkan asing untuk mengolah dan mengambil alih terhadap sumberdaya yang kita miliki. Permasalahan tersebut bukan hanya baru terjadi saat ini, tetapi sudah lama sekitar lima tahun lalu kurang lebih dan belum beranjak membaik hingga saat ini. Berbagai permasalahan tersebut, hanya bisa diatasi bila mayoritas bangsa berupaya bahu membahu maupun mendukung untuk terbentuknya good governance.

Pada keadaan seperti tulah Good and Clean Government diperlukan. Pemerintahan yang baik itu hanya bisa dibangun melalui pemerintahan yang bersih (clean government) dengan aparatur birokrasinya yang terbebas dari segala bentuk kecurangan publik, seperti Korupsi, Kolusi dan Nepotisme (KKN). Clean government patut menjadi sebuah perhatian khusus dewasa ini, karena spektrum korupsi di Indonesia sudah merasuk di hampir semua sisi kehidupan kenegaraan dan kemasyarakatan. Mulai dari hal terkecil dalam pembuatan KTP, hingga peluang terbesar yaitu IMB, tender proyek-proyek BUMN, penjualan aset negara oleh BPPN, penggerogotan dana Bulog, dan bahkan kitab suci pun dijadikan sebagai alat untuk melakukan tindak KKN tersebut. Sampai akhirnya pun pegawai atau pekerja yang menjadi bawahan dan pekerja kecil sudah mulai terbiasa melakukan tindakan korupsi seperti itu, karena adanya lingkungan yang melakukan hal kecurangan di sekitarnya, seperti tukang parkir dan penjual tiket kereta api.

Tetapi sejujurnya korupsi adalah masalah klasik yang dialami dan terjadi saat ini. Secara tidak langsung korupsi dipengaruhi oleh:

1. Kualitas birokrasi, banyak jabatan dalam birokrasi yang memberikan banyak keuntungan, sehingga nepotisme, kolusi, patronage banyak terjadi.

2. Tingkat gaji birokrat, Tingkat gaji yang rendah padahal birokrat tersebut mengelola uang negara yang banyak, sehingga banyak godaan untuk melakukan korupsi.

3. Institusional control, pemberian reward dan punishment, sehingga birokrat menjadi termotivasi untuk menjadi lebih baik dan takut untuk berbuat yang melanggar peraturan.

Jadi solusi yang baik untuk menerapkan Good and Clean Government yang baik adalah adanya kerjasama yang baik antar pemerintahan, keterbukaan atas apa 
yang sedang ataupun yang telah terjadi di dalam ranah pemerintahan kepada masyarakat, adanya pengakuan atau partisipasi masyarakat diakui, keikut sertaan publik dalam mengambil suatu kebijakan yang berarti mementingkan kepentingan publik bukan hanya kepentingan beberapa orang saja, adanya efisiensi, efektifitas, dan berkesinambungan suatu organisasi, legitimasi organisasi yang dikelola dengan terbuka, adil, dan dapat dipertanggungjawabkan, mengakui dan melindungi hak dan kewajiban para stakeholders, dan pendekatan yang terpadu berdasarkan kaidahkaidah demokrasi, pengelolaan dan partisipasi organisasi secara legitimate

\section{KESIMPULAN}

1. Prosedur dan mekanisme yang implementatif dalam penyelenggaraan good governance dan pemerintahan yang baik adalah terselenggaranya pemerintahan yang baik, bersih dan berwibawa (clean and good governance) menjadi cita-cita dan harapan setiap bangsa. Governance adalah mekanisme pengelolaan sumber daya ekonomi dan sosial yang melibatkan pengaruh sektor Negara dan sektor non pemerintah dalam suatu kegiatan kolektif. Good dalam good gavernance, mengandung 2 (dua) pengertian bahwa nilai-nilai yang menjunjung tinggi keinginan/kehendak rakyat, dan nilai-nilai yang dapat meningkatkan kemampuan rakyat yang dalam pencapaian tujuan (nasional) kemandirian, pembangunan berkelanjutan dan keadilan social.

2. Usaha-usaha yang harus dilakukan dalam meningkatkan pemahaman seluruh komponen stake holders tentang good governance dan pemerintahan yang baik adalah bahwa governance dan good governance pada dasarnya tidak diatur dalam sebuah undang-undang (UU). Tetapi dapat dimaknai bahwa governance adalah tata pemerintahan, penyelenggaraan negara, atau management (pengelolaan) yang artinya kekuasaan tidak lagi semata-mata dimiliki atau menjadi urusan pemerintah. Governance itu sendiri memiliki unsur kata kerja yaitu governing yang berarti fungsi pemerintah bersama instansi lain (LSM, swasta dan warga negara) yang dilaksanakan secara seimbang dan partisipatif.

3. Realitas penegakan hukum terhadap Pegawai Negeri Sipil yang melakukan pelanggaran disiplin dan atau melakukan tindak pidana Perbuatan pemerintah yang tercela dalam hukum tata administrasi negarasering disebut perbuatan penguasa yang sewenang-wenang (willekeur). Perbuatansewenangwenang pemerintah frekuensinya lebih banyak terjadi dalampenyelenggaraan pemerintahan yang bersifat bebas (vrij bestuur). Dalampenyelenggaraan pemerintahan yang bersifat mengikat (gebonden bestuur)perbuatan tersebut jarang terjadi. Terdapat pelanggaran- 
pelanggaran yang dilakukan oleh Pegawai Negeri Sipil. Banyak pejabat negara atau PNS yangmenyalahgunakan

wewenang atau melakukan pertentangan kepentingan denganmenghalalkan segala cara. Pelanggaran-pelanggaran yang banyak dilakukan olehPNS berupa Korupsi, Pelanggaran Disiplin, Penyalahgunaan Wewenang, ikutberkampanye dan lain-lain. Pasal 4 Peraturan Pemerintah Nomor 53 Tahun 2010 tentang Disiplin Pegawai Negeri Sipil memuat tingkat dan jenis hukuman disiplin, yaitu:Hukuman disiplin ringan terdiri dari: Teguran lisan, Teguran tertulis, Pernyataan tidak puas secara tertulis.

\section{DAFTAR PUSTAKA}

Ateng Syafrudin. Mепијu Penyelenggaraan Pemerintah Negara yang Bersih dan Bertanggungjawab, ProJustitia Tahun XVIII Nomor 4, Oktober 2000 OeripS, FX, Poerwopoespito,Mengatasi

Krisis Manusia di Perusahaan, Solusi Melalui Pengembangan Sikap Mental, Grasindo, Jakarta, 2000.

Muchsan,HukumKepegawaian,Jakart a:BinaAksara, 1982.

Radar.Cirebon.16februari2012, http://radarcirebon.com/ 2012/02/16/27-pns-

dijatuhi-sanksi

diakses11April 2019.

Syafrudin, Ateng, Menuju
Penyelenggaraan Pemerintah

Negara yang Bersih dan

Bertanggungjawab, ProJustitia Tahun XVIII Nomor 4, Oktober 2000.

Siregar, P. (2019). PENGARUH DISIPLIN KERJA DAN PENGUASAAN

TEKNOLOGI INFORMASI TERHADAP KINERJA

PEGAWAI DI

UNIVERSITAS DARMA

AGUNG. Jurnal Darma Agung, 27(1), 785 - 796. doi:10.46930/ojsuda.v27i1.13 3

Panggabean, N. (2018). PENGARUH

LINGKUNGAN KERJA DAN PENGELOLAAN STRES KERJA TERHADAP KINERJA PEGAWAI UNIVERSITAS DARMA AGUNG. Jurnal Darma Agung, 26(1), 510-521. Retrieved from https://jurnal.darmaagung.ac.i d/index.php/jurnaluda/article/ view $/ 90$ 